\title{
Ilmarinen - Viron presidentin ja ylipäällikön konepaja
}

\author{
Veijo Kauppinen
}

Raudan käytön yleistymisellä oli suuri vaikutus itämerensuomalaiseen mytologiaan. Ilmarisestakin tuli tällöin Seppo tai takoja iän ikuinen.

Virossa oli jo 1800-luvulla metallialan teollista käsityötä harjoittavia yrityksiä, kuten Tallinnan suurin Fr. Wiegandi Tallinna Masinaehitustehas. Konepaja Ilmarinen, viroksi Ìlmarine, laskee juurensa alkavaksi tästä vuonna 1859 perustetusta verstaasta. İlmarisen perustamisen oikeampi ajankohta lienee kuitenkin vuosi 1920, jolloin joukko Viron liike-elämän ja politiikan eliittiin kuuluvia henkilöitä perusti Ilmariseksi ristityn konepajan. Heihin kuuluivat Viron historian polttopisteeseen joutuneet pääministeri ja myöhempi presidentti Konstantin Päts sekä yhtiön hallituksen puheenjohtaja, Viron armeijan ylipäällikkö Johan Laidoner.

Ilmarisen jyhkeä, harmaakivinen rakennus sijaitsee Pohja Pst:n ja Suur Patarein rajaamassa kolmiossa. Lähellä ovat laivaterminaalit ja Baltian asema, vanha kaupunki, Kalasatama sekä Lentosataman merimuseo.

Ilmarisen omistus siirtyi vuonna 1924 perheyritykselle J. Puhk ja Pojad, jolla oli ennestään autoedustuksia, Ilmarisen tuolloiset tuotteet olivat höyrykoneita, teräsrakenteita, aseita sekä tislaamojen ja paperitehtaiden laitteita. Merkittävä tuote oli myös Russ-naftamoottori. Ensimmäiset virolaiset tiehöylät tulivat konepajan valmistusohjelmaan 1930-luvulla. Niiden esikuvaksi hankittiin kaksi ruotsalaista höylää.

Pätsin ja Laidonerin myöhempi kohtalo oli koko Viron historian lailla kova kummankin kadotessa jäljettömiin. Kunnian palautuksen he Viron uuden itsenäisyyden myötä kuitenkin saivat.

Lähellä Tallinnaa Viimsissä sijaitseva, vuonna 1919 perustettu Viron sotamuseo avattiin vuonna 2001 entisöitynä nimellä "Viron sotamuseo - kenraali Laidonerin museo" keräämään, tutkimaan ja esittelemään virolaista sotahistoriaa ja perinnekulttuuria.

Ilmarinen kansallistettiin 1940-luvun alkuvuosina ja alistettiin Lennukitööstuse Rahvakomissariaadille. Siitä kehittyi Baltian merkittävin teräsrakenteiden ja koneiden valmistaja. Vuonna 1944 Ilmarisen nimeksi tuli Tallinna II Masinaehitustehas. Se toimi neuvostoViron aikana useiden eri ministeriöiden alaisena, viimeksi vuodesta 1975 alkaen energia- ja koneenrakennusministeriön. Konepajan tuotteet vaihtelivat, se valmisti mm. raitiovaunuja.

Viron toisen tasavallan hallitus päätti vuonna 1994 myydä valtion omistamia tehtaita. Ilmarisen tiheät omistusjärjestelyt ja konepajan pilkkomiset seurasivat toisiansa. Konepajan taival oli tuskainen ja raskaiden tappioiden sävyttämä. Vuonna 2004 esimerkiksi sillä oli tuskin lainkaan toimintaa. Strateginen virhe oli suunnata tuotteisto Venäjän markkinoille, joita ei sitten ollutkaan. Konepaja toimi useilla nimillä. Viimeisinä vuosinaan perinteisellä paikallaan sijainnut kahden yksityishenkilön omistamana konepaja oli nimeltään ASi Ilmarine.

Konepaja muutti keskustasta Maardun teollisuuspuistoon, jossa sen tuotteita ovat olleet suomalaistenkin tilaamat teräsrakenteet, alumiinivalmisteet sekä koneiden ja laivojen osarakenteet.

Ilmarisen teollisuushistoriaa henkivä rakennus on nykyisin konepajan perinteitä vaaliva 105 huoneen Hestia Hotel Ilmarine.

Lähteenä on käytetty mm. artikkelia: Ilmarine kujunes Pätsu ajal rahvusliku tööstuse teerajakajaks. Äripäev Tööstus, november 2007, ajalugu s. 58. 